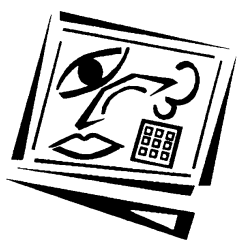

\title{
Analysing high school students' participation and interaction in an asynchronous online project-based learning environment
}

\author{
Quek Choon Lang \\ Nanyang Technological University
}

\begin{abstract}
This study aims to replicate and extend a previous study which was conducted on primary school students' asynchronous online project-based learning. In this study, 276 high school students' participation and interaction in a project-based learning environment was mediated by an asynchronous computer-mediated communication (CMC) tool. The students' high participation revealed their adaptability to this teacher-facilitated learning environment. However, in terms of interaction, these students' notes were found congregating mainly in phase I (comparing and sharing information, $82.7 \%$ ) but lesser extent in the subsequent phase II (the discovery and exploration of dissonance or inconsistency among ideas, concepts or statement, $13.5 \%$ ), phase III (negotiation of meaning/co-construction of knowledge, 3.7\%) and beyond when these notes were analysed using Gunawardena's Interaction Analysis Model (IAM) (1997). These findings were compared, discussed and referenced to the earlier research conducted in the primary school to surface gaps for future research that will focus on addressing obstacles to students' learning issues pertaining to participation and interaction socially and cognitively in such a learning environment.
\end{abstract}

\section{Introduction}

The asynchronous online project-based learning environment is built upon the thrust of constructivist theoretical framework on how people learn and that learning is both an active and a constructive process which is supported by a computer-mediated communication tool. Psycho-social, pedagogical and technological are the key aspects that define design of the asynchronous online project-based learning environment. To reiterate, the pedagogical design of the environment facilitates students' inquiry, collaborative and self-directed learning. Technological design identifies the affordances of technology to support learners' higher order thinking, learning and access in an 'anytime and anywhere' mode. Psycho-social design of the environment focuses on learners' behaviours, attitudes, motivation and interaction that are key considerations to effective management of online learning communities. In this study, an asynchronous computer-mediated communication (CMC) tool is incorporated to provide an asynchronous online project-based learning environment for learners to communicate and collaborate beyond the physical constrains of classroom time via the discussion forums (Romiszowski \& Mason, 2004; Black, 2005; Yeo \& Quek, 2008). As an instructional approach, asynchronous online discussions support dialogue, critical reflection, self-assessment and independent learning by learners (Kayler \& Weller, 2007). Learners' involvement in the asynchronous learning environment is seen from their online participation and interaction. As a learner-directed activity, participation requires the learners to take ownership of learning by gaining access to the forum, 
reading, reflecting and responding to the notes (an indication of the peers' 'voices') posted in the forums. A point to note is that online participation would not happen without the facilitator's designing of learning structures (Gilbert \& Dabbagh, 2005). Learners' willingness to contribute in the group can be seen from their behaviours such as responding swiftly or slowly to their peers, actively or passively (Knowlton, Knowlton \& Davis, 2000). Socially, such a learning environment has the potential to help learners feel a sense of belonging to a group; so long as they feel safe with each other, then they will tend to cooperate and build shared ideas through their interaction with peers.

Past studies have evaluated the quality of online messages in terms of co-construction of knowledge, social presence, cognitive presence and critical thinking, using various content analysis models developed by pioneer researchers (Hiltz, 1990; Mason, 1991; Henri, 1992; Newman, Webb \& Cochrane, 1995; Gunawardena, Lowe \& Anderson, 1997; Garrison, Anderson \& Archer, 2001). These models usually define a group of factors that can be identified in the text and help identify different types of content encountered (Hew \& Cheung, 2003). For example, Henri (1992) developed a detailed model for content analysis that relies on breaking down the transcript into "units of meaning" (a message or a part of it), and classifying these units into categories and sub-categories according to expressions within the units. Then Gunawardena et al. (1997) extended Henri's model (1992) and integrated a participation component into their proposed interaction analysis model, in which interaction is the process through which negotiation of meaning and co-construction of knowledge occurs in a constructivist learning environment.

The Interaction Analysis Model (IAM) was developed to examine the process of knowledge construction with learner participants in a constructivist learning environment that can arrive at a higher level of critical thinking through different phases of interactions with peers (Gunawardena et al., 1997). In other words, content analysis studies allow observations to be made about the social and cognitive interactions between learners, levels of participation, the collaborative activity between learners, and the level of knowledge construction for the learners. The research gap identified was that there was no research conducted on high school students' projectbased learning in asynchronous online project-based environment after the first study of asynchronous online project based learning was conducted at the primary school level (Jamaludin \& Quek, 2006). The findings showed that almost $86 \%$ of the students' notes were found to be low level notes residing in Phases I and II based on the coding scheme from Gunawardena et al., (1997) stating that the five phases of knowledge construction are necessary for co-construction of new knowledge in the collaborative learning setting, thus a very low percentage of high level notes would imply an unsatisfactory quality of knowledge co-construction among the learners. Three research questions are:

1. What was the extent of students' participation based on their posting and reading of notes in an asynchronous online project-based learning environment?

2. What type of notes did students post in the asynchronous online project-based learning environment?

3. What was the extent of project learning based on students' interaction in the asynchronous online project-based learning environment? 


\section{Method}

\section{Sample}

The sample consisted of 276 high school students (14-15 year olds) who came from a typical secondary school situated in the western part of Singapore. Consent was obtained from the school and the participants prior to the conduct of this study. There were 45 project groups comprising of 6-7 students in each project group. In terms of English language reading and writing skills, these students showed differing levels of command of English language (based on their secondary one end of year examination results). They came from the Express stream classes (consisting of students of average ability). These students embarked on the project task 'Designing game for teenagers'.

\section{Procedure}

The students were introduced to the asynchronous online discussion forum found in the asynchronous CMC tool, Knowledge Community $(\mathrm{KC})$. There were scaffolds such as 'I agree' and 'My opinion' designed within the discussion forums to support students' thinking and their articulation of thinking more explicitly. The teachers also customised appropriate scaffolds for students to use in their discussion notes by revising the existing scaffolds based on the students' feedback and request. For example, the scaffolds used are "I learn from my parents', 'My analysis of the game design' and 'I would suggest the steps'. The teachers also demonstrated by modeling "good" notes and "bad" notes in class so as to help students communicate their notes clearly and to proceed with the threaded discussions confidently. The students were also provided with opportunities to assume roles (e.g. participants and facilitator) and to take turns to practise articulating project ideas, asking questions and consolidating group ideas. The teacher also instituted ground rules such as using appropriate language and seeking clarifications by asking questions. To provide structure to the students' learning, the project teachers planned for eight weekly online discussion forums for students to participate weekly. The teachers' role in online facilitation involved three types of moves such as intervening when the students either went off focus, or were stuck with interpersonal and learning issues, fading out when the students were progressing or were on track and making frequent online visits to the forums.

Students' asynchronous online learning took place after the formal school hours where students used the library or home computers to access the forums and to discuss their projects with their team members. Project teachers facilitated their students' online discussions after the formal school hours but they taught "just in time" project skills in the face to face classroom setting.

\section{Data analysis}

\section{Participation}

To analyse students' online participation, this study used the built-in function called 'Analysis' in Knowledge Community. The frequency of student participation (notes read and posted by the individual student in the forums) could be generated and calculated for each forum. To investigate the characteristics of students' notes, students' online transcripts were analysed and categorised in three areas: the focus of the note (on or off-topic), feedback from the note (positive, negative, neutral) and function of the note (to provide information, ask clarification or something else). These 
three areas were based on the pioneer research work conducted in schools and colleges between the late 1990s and early 2000 (Chi, 1997; Hakkarainen, 1998; Lipponen, 2000; Lipponen, Rahikainen, Lallimo \& Hakkarainen, 2003, Lipponen \& Lallimo, 2004; Lakkala, Lallimo \& Hakkarainen, 2005).

Table 1: Overview of project work teaching and learning

\begin{tabular}{|c|c|c|c|}
\hline \begin{tabular}{|c|} 
Domains of \\
project \\
learning
\end{tabular} & $\begin{array}{c}\text { Focus of } \\
\text { project learning }\end{array}$ & $\begin{array}{l}\text { Project } \\
\text { skills }\end{array}$ & $\begin{array}{c}\text { Examples of teachers' } \\
\text { teaching activities }\end{array}$ \\
\hline $\begin{array}{l}\text { Knowledge } \\
\text { acquisition } \\
\text { and } \\
\text { application }\end{array}$ & $\begin{array}{l}\text { Process } \\
\text { - Information gathering } \\
\text { - Processing of information } \\
\text { (including the design proc- } \\
\text { ess for intervention tasks) } \\
\text { - Evaluation of work towards } \\
\text { improvement } \\
\text { Product } \\
\text { - Application of knowledge } \\
\text { from various subjects and } \\
\text { - } \text { project skills } \\
\text { - } \text { purveying of intent/ } \\
\text { Evidence of creativity / } \\
\text { thoughtfulness }\end{array}$ & $\begin{array}{l}\text { - Analysis } \\
\text { - Creativity and } \\
\text { thoughtfulness } \\
\text { - Communication } \\
\text { of intent/ } \\
\text { purpose of } \\
\text { project task to } \\
\text { target audience }\end{array}$ & $\begin{array}{l}\text { Use the online graphic } \\
\text { organisers for analysing } \\
\text { and making decisions in } \\
\text { asynchronous online } \\
\text { environment } \\
\text { - Teach Internet search, } \\
\text { creating links in the online } \\
\text { asynchronous } \\
\text { environment } \\
\text { - Questioning techniques } \\
\text { for learning }\end{array}$ \\
\hline $\begin{array}{l}\text { Communic- } \\
\text { ation }\end{array}$ & $\begin{array}{l}\text { - } \text { Clarity } \\
\text { - Coherence } \\
\text { - Effectiveness of aids } \\
\text { - } \text { Managing questions }\end{array}$ & $\begin{array}{l}\text { - Oral communi- } \\
\text { cation } \\
\text { - Use of visuals / IT }\end{array}$ & $\begin{array}{l}\text { Teach 'what to do before, } \\
\text { during and after discuss- } \\
\text { ion' skills for face to face } \\
\text { and online environment } \\
\text { - Orientate participants in } \\
\text { the 'How are you?' forum }\end{array}$ \\
\hline $\begin{array}{l}\text { Collaborat- } \\
\text { ion }\end{array}$ & $\begin{array}{l}\text { - Completion of tasks as } \\
\text { scheduled } \\
\text { - Fair allocation of tasks } \\
\text { - Contribution to project }\end{array}$ & $\begin{array}{l}\text { - } \text { Time } \\
\text { management } \\
\text { - Conflict } \\
\text { resolution } \\
\text { - Teamwork }\end{array}$ & $\begin{array}{l}\text { Introduce team building in } \\
\text { the face to face setting } \\
\text { - Questioning techniques } \\
\text { for collaborative learning } \\
\text { - Monitor each member's } \\
\text { contribution }\end{array}$ \\
\hline $\begin{array}{l}\text { Independent } \\
\text { learning }\end{array}$ & $\begin{array}{l}\text { - Plan and monitor his/her } \\
\text { own work } \\
\text { - Attitude towards own } \\
\text { learning } \\
\text { - Know when to seek help }\end{array}$ & $\begin{array}{l}\text { Writing } \\
\text { reflections for } \\
\text { - self evaluation } \\
\text { - self motivation } \\
\text { - project group }\end{array}$ & $\begin{array}{l}\text { - } \text { Teach writing of } \\
\text { individual and group } \\
\text { reflections }\end{array}$ \\
\hline
\end{tabular}

Source: Adapted from Ministry of Education, 1999

\section{Interaction}

Students' online transcripts were analysed qualitatively using the Gunawardena et al. (1997) interaction analysis model (IAM, Figure 1) based on the five phases of knowledge co-construction that occur during the online discussions in the project classrooms. The IAM enables us to identify students' interaction during the online discussions that correspond to their project building process from forming groups and communicating ideas. Each note from the students' transcripts was coded according to the schema of the model. These include: sharing/comparing, exploration of dissonance, negotiation/ co-construction, testing tentative constructions, and statement/ applications of newly constructed knowledge. According to Gunawardena et al. (1997), notes ranked in Phase I and Phase II are considered to "represent the lower mental functions", while notes rated in Phase III, Phase IV, and Phase V "represent the higher mental functions" 
(Beaudrie, 2000). However, in this context, in view of the normal high school population, I regard Phase I as low mental level but from Phases II to IV, I would regard them as high mental level. This would be regarded as the point of departure from the original interpretation of the IAM model used in this study.

The units of analysis used to analyse knowledge constructed was the thematic unit that refers to a single thought unit or an idea that was considered relevant to providing critical feedback to the peers (Hew \& Cheung, 2003). Two raters coded the online transcripts using Lipponen's (2000) indicators on type of notes and Gunawardena et al's (1997) IAM. For this study, the researcher used IAM as a guide to identify students' participation notes residing in Phase I as the lower mental and participation notes residing in Phases 2 to 4 as higher mental notes under the umbrella of students' project-based learning.

\begin{tabular}{|c|c|c|c|}
\hline \multicolumn{2}{|l|}{ Phase } & \multicolumn{2}{|l|}{ Operations which occur at this stage include: } \\
\hline \multirow{5}{*}{$\begin{array}{l}\text { Phase I } \\
\text { Sharing / comparing } \\
\text { of information }\end{array}$} & A. & A statement of observation or opinion & {$[\mathrm{PhI} / \mathrm{A}]$} \\
\hline & B. & A statement of agreement from one or more participants & {$[\mathrm{PhI} / \mathrm{B}]$} \\
\hline & C. & $\begin{array}{l}\text { Corroborating examples provided by one or more } \\
\text { participants }\end{array}$ & {$[\mathrm{PhI} / \mathrm{C}]$} \\
\hline & D. & $\begin{array}{l}\text { Asking and answering questions to clarify details of } \\
\text { statements }\end{array}$ & {$[\mathrm{PhI} / \mathrm{D}]$} \\
\hline & E. & Definition, description, or identification of a problem & {$[\mathrm{PhI} / \mathrm{E}]$} \\
\hline \multirow{3}{*}{$\begin{array}{l}\text { Phase II } \\
\text { The discovery and } \\
\text { exploration of } \\
\text { dissonance or } \\
\text { inconsistency among } \\
\text { ideas, concepts or } \\
\text { statements }\end{array}$} & A. & Identifying and stating areas of disagreement & {$[\mathrm{PhII} / \mathrm{A}]$} \\
\hline & B. & $\begin{array}{l}\text { Asking and answering questions to clarify the source } \\
\text { and extent of disagreement }\end{array}$ & {$[\mathrm{PhII} / \mathrm{B}]$} \\
\hline & C. & $\begin{array}{l}\text { Restating the participant's position, and possibly } \\
\text { advancing arguments or considerations in its support by } \\
\text { references to the participant's experience, literature, } \\
\text { formal data collected, or proposal of relevant metaphor } \\
\text { or analogy to illustrate point of view }\end{array}$ & {$[\mathrm{PhII} / \mathrm{C}]$} \\
\hline \multirow{5}{*}{$\begin{array}{l}\text { Phase III } \\
\text { Negotiation of } \\
\text { meaning/ co- } \\
\text { construction of } \\
\text { knowledge }\end{array}$} & A. & Negotiation or clarification of the meaning of terms & {$[\mathrm{PhIII} / \mathrm{A}]$} \\
\hline & B. & $\begin{array}{l}\text { Negotiation of the relative weight to be assigned to } \\
\text { types of argument }\end{array}$ & {$[\mathrm{PhIII} / \mathrm{B}]$} \\
\hline & C. & $\begin{array}{l}\text { Identification of areas of agreement to overlap among } \\
\text { conflicting concepts }\end{array}$ & {$[\mathrm{PhIII} / \mathrm{C}]$} \\
\hline & D. & $\begin{array}{l}\text { Proposal and negotiation of new statements embodying } \\
\text { compromise, co-construction }\end{array}$ & [PhIII/D] \\
\hline & E. & $\begin{array}{l}\text { Proposal of integrating or accommodating metaphors or } \\
\text { analogies }\end{array}$ & {$[\mathrm{PhIII} / \mathrm{E}]$} \\
\hline \multirow{5}{*}{$\begin{array}{l}\text { Phase IV } \\
\text { Testing and } \\
\text { modification of } \\
\text { proposed synthesis or } \\
\text { co-construction }\end{array}$} & A. & $\begin{array}{l}\text { Testing the proposed synthesis against "received fact" as } \\
\text { shared by the participants and/or their culture }\end{array}$ & {$[\mathrm{PhIV} / \mathrm{A}]$} \\
\hline & B. & Testing against existing cognitive schema & {$[\mathrm{PhIV} / \mathrm{B}]$} \\
\hline & C. & Testing against personal experience & {$[\mathrm{PhIV} / \mathrm{C}]$} \\
\hline & D. & Testing against formal data collected & {$[\mathrm{PhIV} / \mathrm{D}]$} \\
\hline & E. & Testing against contradictory testimony in the literature & {$[\mathrm{PhIV} / \mathrm{E}]$} \\
\hline \multirow{3}{*}{$\begin{array}{l}\text { Phase } V \\
\text { Agreement } \\
\text { statements(s)/ } \\
\text { applications of newly } \\
\text { constructed meaning }\end{array}$} & A. & Summarisation of agreement(s) & {$[\mathrm{PhV} / \mathrm{A}]$} \\
\hline & B. & Applications of new knowledge & {$[\mathrm{PhV} / \mathrm{B}]$} \\
\hline & C. & $\begin{array}{l}\text { Metacognitive statements by participants illustrating } \\
\text { their understanding that their knowledge or ways of } \\
\text { thinking (cognitive schema) have changed as a result of } \\
\text { the conference interaction }\end{array}$ & {$[\mathrm{PhV} / \mathrm{C}]$} \\
\hline
\end{tabular}

Figure 1: Coding schema of the interaction analysis model (Gunawardena et al., 1997) 


\section{Findings}

\section{Research question 1}

What was the extent of students' participation based on their posting and reading of notes in an asynchronous online project-based learning environment?

The students' and teacher-facilitators' notes were included in Table 2. In terms of students' frequency of reading and posting of notes, it was found that students read more frequently than posted notes. There was a decreasing trend of student participation. For example, Forum 1 showed the highest participation while Forum 8 showed the least participation by students. The decreasing trend was observed from Forums 1 to 4 with Forums 3 and 4 showing almost similar number of notes contributed and read by students, a marked decrease was observed in Forum 5 followed by a sharp increase in Forum 6 but a sharp decrease in Forums 7 and 8 . The participation issues emerged showed that first of all, students dominated the discussion, not the facilitators; a finding that indicated that this discussion was at least somewhat student-centred. Table 2 shows a breakdown of the notes posted throughout the study. Notes posted in Forums 8 and beyond were not coded as it was beyond the allocated 2 months duration.

Table 2: Students' frequency of participation notes posted and read in weekly online discussion forums

\begin{tabular}{|c|c|c|c|l|}
\hline $\begin{array}{c}\text { Weekly } \\
\text { forum }\end{array}$ & $\begin{array}{c}\text { Total no. of } \\
\text { notes read by } \\
\text { students }\end{array}$ & $\begin{array}{c}\text { Total no. of } \\
\text { teacher-facilitator } \\
\text { notes (as a } \\
\text { reference point) }\end{array}$ & $\begin{array}{c}\text { Total no. of } \\
\text { student notes } \\
\text { posted by } \\
\text { students }\end{array}$ & \multicolumn{1}{|c|}{$\begin{array}{c}\text { Weekly focus of the } \\
\text { forums facilitated by teachers }\end{array}$} \\
\hline 1 & 2911 & 55 & 2856 & $\begin{array}{l}\text { To get to know one another in the } \\
\text { project group }\end{array}$ \\
\hline 2 & 1119 & 20 & 1099 & To contribute project ideas by members \\
\hline 3 & 1512 & 79 & 1433 & $\begin{array}{l}\text { To define, ask questions and improve } \\
\text { the project ideas contributed }\end{array}$ \\
\hline 4 & 1546 & 75 & 1471 & To work on the project collaboratively \\
\hline 5 & 448 & 50 & 398 & To plan for project presentation \\
\hline 6 & 1127 & 11 & 1116 & $\begin{array}{l}\text { To critique the group project } \\
\text { presentation }\end{array}$ \\
\hline 7 & 35 & 0 & 35 & To reflect on learning individually \\
\hline 8 & 7 & 0 & 8 & To reflect on learning collaboratively \\
\hline Total & 8705 & 290 & 8415 & \\
\hline & & & & \\
\hline
\end{tabular}

Out of the total number of notes posted, only $3 \%$ were contributed by facilitators. Students participated mainly in their weekly discussion forums. It was found that the students' frequency of reading of notes was higher than their posting of notes. By comparing the students' notes read and posted, information after Forum 6 had reached a "steady" state where there was almost same number of notes present. Beyond Forum 6 , there was a sharp decrease in the frequency of notes posted or read by the students and the facilitators" "voices" were completely absent in the last two forums.

\section{Research question 2}

What type of notes did students post in asynchronous online project-based learning environment? 
The inter-rater coder agreement indicated by the Cohen kappa statistic in all three categories (focus, feedback and function) was 0.85 which was considered satisfactory. In the category of focus, students' notes were coded in two sub-categories. .It was reported students' notes were frequently found to be on topic (79\%) but less frequently found to be off topic (21\%) as shown in Table 3 . The example of the forum provided in Table 3 was based on a group of students who wanted to design a game for their peers and they brainstormed their project ideas. The on topic notes included students' providing information and explanations for fellow students' inquiries. The off topic notes focused on social issues such as greetings and generally school work not related to the students' project task.

Table 3: Categorisation of student's participation notes and frequency of such notes

\begin{tabular}{|c|c|c|c|}
\hline $\begin{array}{l}\text { Categ- } \\
\text { ories }\end{array}$ & \begin{tabular}{|c|} 
Indicators \\
of notes
\end{tabular} & $\begin{array}{l}\text { Example of discussion notes with scaffolds (discussion } \\
\text { forum on exploring project ideas on designing games) }\end{array}$ & $\begin{array}{l}\text { Frequency } \\
(\%)\end{array}$ \\
\hline \multirow[t]{2}{*}{ Focus } & On topic & $\begin{array}{l}\text { [I have evidence] The game involves connective thinking (refer } \\
\text { to the previous "ideas" forums, besides using magical cards, } \\
\text { the "enemies" and the problems faced by the players involves } \\
\text { solving magical problems. [/I have evidence] (Student A) }\end{array}$ & $\begin{array}{l}6645 \\
(79)\end{array}$ \\
\hline & Off topic & $\begin{array}{l}\text { [In my opinion] What game? I have no idea. [/In my opinion] } \\
\text { [I rcall] You are right and if I did not remember wrongly, our } \\
\text { deadline for our project ideas is next Tuesday (or } \\
\text { Wednesday?) We have got a lot of good ideas already, so } \\
\text { maybe we can start choosing soon... [/I rcall] (Student C) }\end{array}$ & $\begin{array}{l}1808 \\
(21)\end{array}$ \\
\hline \multirow[t]{3}{*}{ Feedback } & Positive & $\begin{array}{l}\text { [Reason] Wow! your ideas are very creative and good.. but } \\
\text { why do you all don't approve of violence.. it can make the } \\
\text { game more interesting and fun.. i am sure youngest nowadays } \\
\text { like games to be exciting.. and mostly all exciting and that can } \\
\text { arouse the attention of them is games that includes violence } \\
\text { like runescape or gunbound.. therefore.. i think that violence } \\
\text { should be included too. [/Reason] (Student G) }\end{array}$ & $\begin{array}{c}6316 \\
(75)\end{array}$ \\
\hline & Negative & $\begin{array}{l}\text { [My opinion] I do not agree because I think that violence is not } \\
\text { healthy to children and the teenagers. [/My opinion] (Student } \\
\text { E) }\end{array}$ & $\begin{array}{c}53 \\
(0.6)\end{array}$ \\
\hline & Neutral & [In my opinion] I have no opinion. [/In my opinion] (Student B) & $\begin{array}{l}2084 \\
(24.4)\end{array}$ \\
\hline \multirow[t]{3}{*}{ Function } & \begin{tabular}{l|}
$\begin{array}{l}\text { Providing } \\
\text { inform- } \\
\text { ation }\end{array}$ \\
\end{tabular} & $\begin{array}{l}\text { [In my opinion] Many parents hate violence as violence } \\
\text { influence a lot on children, they are worried that their children } \\
\text { will become violent. I will suggest that we had better not } \\
\text { include violence. It is not always that computer games must } \\
\text { have violence and will be fun. [/In my opinion] (Student E) } \\
\text { [My suggestion] We can create something more interesting } \\
\text { other then violence, think... ideas just come, even from daily } \\
\text { lives, we should be more innovative. I just came up with a } \\
\text { setting for the game, how about skycastle or skycity? } \\
\text { (Inspiration from Laputa, Lilliput). I hope you all can consider } \\
\text { about this idea. [/My suggestion] (Student F) }\end{array}$ & $\begin{array}{l}4448 \\
(53)\end{array}$ \\
\hline & \begin{tabular}{|l|} 
Asking \\
clarific- \\
ation
\end{tabular} & $\begin{array}{l}\text { [My question] Are you saying all computer games must } \\
\text { include violence? Why? [/My question] (Student D) }\end{array}$ & $\begin{array}{c}1179 \\
(14)\end{array}$ \\
\hline & \begin{tabular}{|l|} 
Others \\
(unrelated \\
/ not \\
useful \\
notes to \\
the group)
\end{tabular} & $\begin{array}{l}\text { [My opinion] Hey people, the computers here are very slow } \\
\text { and the server is busy... we cannot (both from bpghs) meet on } \\
\text { thursday because we are still in school!!!! hey perhaps we can } \\
\text { meet on either this friday (at night around } 19.00 \text { or 20.00) or } \\
\text { saturday (any time except for midnight.. and morning) maybe } \\
14.00 \text { can?? [/My opinion] }\end{array}$ & $\begin{array}{c}2826 \\
(33)\end{array}$ \\
\hline
\end{tabular}


In the category of feedback, students' notes were coded in three sub-categories. It was reported that these students' notes frequently gave positive feedback (75\%). It was found that students' remaining neutral to giving feedback was $24.4 \%$ but there was hardly any negative feedback as indicated by the low percentage $(0.6 \%)$. In other words, students indicated higher frequency in providing positive feedback than the other two sub-categories. It would be necessary to find out why students remained neutral and why students tended to provide positive feedback to their peers in this asynchronous project-based learning environment.

In the category of function, students' notes were coded in three sub-categories. It was reported that students' notes frequently provided information to their peers $(53 \%)$ and to some extent also showed unrelated notes found under others $(33 \%)$ but least frequently in asking for clarification (14\%). These students' notes were generally comprehensible except a handful of the incomprehensible notes were treated as unrelated under the sub-category, off topic.

\section{Research question 3}

What was the extent of project learning based on students' interaction in the asynchronous online project-based learning environment?

Students' project learning was investigated by analysing the participation notes, guided by the phases found in the IAM model. The inter-rater coder agreement indicated by the Cohen kappa statistic in all categories (sharing/comparing, exploration of dissonance, negotiation/co-construction, testing tentative constructions, and statement/applications of newly constructed knowledge) was 0.8 which was considered satisfactory. To understand the level of thought building and knowledge construction that occurred in the online environment, a further analysis of the content of students' notes according to the IAM (Gunawardena et al, 1997) was conducted. Table 4 shows the extent of low mental level notes (based on phase I) and high mental notes (based on phases II to V) that occurred in the asynchronous online project-based learning environment.

Table 4: Students' notes analysed according to the interaction analysis model (IAM) (Gunawardena et al, 1997) in project learning

\begin{tabular}{|c|c|c|c|c|c|}
\hline \multirow{2}{*}{$\begin{array}{l}\text { Weekly } \\
\text { forum }\end{array}$} & \multicolumn{5}{|c|}{ Students' project learning } \\
\cline { 2 - 6 } & $\begin{array}{c}\text { Low mental } \\
\text { level notes }\end{array}$ & \multicolumn{4}{c|}{ High mental level notes } \\
\cline { 2 - 6 } & Phase 1 & Phase 2 & Phase 3 & Phase 4 & Phase 5 \\
\hline 1 & 1890 & 367 & 112 & 3 & 2 \\
\hline 2 & 807 & 153 & 48 & 1 & 0 \\
\hline 3 & 1105 & 162 & 60 & 0 & 0 \\
\hline 4 & 1178 & 179 & 49 & 0 & 0 \\
\hline 5 & 239 & 70 & 4 & 0 & 0 \\
\hline 6 & 981 & 80 & 8 & 0 & 0 \\
\hline 7 & 22 & 4 & 0 & 0 & 0 \\
\hline 8 & 6 & 2 & 0 & $5(0.07 \%)$ & $2(0.03 \%)$ \\
\hline Total & $6228(82.7 \%)$ & $1017(13.5 \%)$ & $281(3.7 \%)$ & 0 \\
\hline
\end{tabular}

The findings showed that most of the forum messages were found residing in phase 1 of comparing and sharing information which was treated as lower mental notes $(82.7 \%)$ while a small percentage of the messages were found in phases 2 to 4 contributing to 
What is Gunbound like? by S2 9:56:56

What is Gunbound like?

Okay by S3 22:26:36

I think gunbound can be included in the game. Can it be a part of the computer game? I will suggest that the gun will not be used to kill enemies but to shoot targets. No bloodshed scenes. How about designing the plot for the game as a kind of adventure? We will need to design characters for different age players. For eg, cute characters to attract young children, and "cool" characters to attract teenagers. Adult, maybe more elegant and in style. Not forgetting old players, the characters may be in traditional and outdated costume in the ancient times. How about having the

adventure in a maze garden or even, maze world, to train player's mind and set them thinking. There will be magical and exciting things going on. Players do not fight enemies with weapons that cause bloodshed scenes. The players have to think and making full use of the magical powers given to them smartly in order to win the game. I will elaborate further on my ideas in the next forum as it will be too long to say it all out at one go.

Question by $S 1$ 22:48:52

Is it alright to insert images? I need images to express my ideas.

More ideas by S1 9:2:28

How about besides of gunbound, include other "tools" for shooting targets? Eg, Arrows, javeline, bubble gun etc. (anything you can think of...) As for the setting of the game, there can be many landscapes, maze, under-water world, fantasy land, magical street, deep forest etc (Give more ideas!). Design characters with different background and story, the players holds the fate of the character, different results with different endings.

Good idea... yeah, I almost forgot! by S4 20:27:43

Hey your idea is really good... Hmm, we would have to work on that but how many members are there in the school that we are working with... why does it seem that there is only two.. Where are the others?? Yeah! I almost forget we are only doing the proposal only... In my mind, I always tot that we have to carry out the idea... Hmm... let's work harder!

Reason to include violence? by S5 11:42:30

Wow! your ideas are very creative and good.. But why do you all don't approve of violence? It can make the game more interesting and fun.. I am sure youngsters nowadays like games to be exciting. That is why games should include violence just like Runescape or Gunbound.. Therefore, I think violence should be included in our design too.

Disagreement? S4 1:20:20

I do not agree because I think that violence is not healthy to children and the teenagers.

Opinion by 54 2:26:36

Many parents hate violence as violence influence a lot on children, they are worried that their children will become violent. I will suggest that we had better not include violence. It is not always that computer games must have violence and will be fun.

Opinion by S3 4:25:10

We can create something more interesting other then violence, think... ideas just come, even from daily lives, we should be more innovative. I just came up with a setting for the game, how about skycastle or skycity? (Inspiration from Laputa,

Lilliput). I hope you all can consider about this idea.

Figure 2: Dialogue among students 
high mental level notes $(17.3 \%)$. The content of phase I notes were mostly about students' stating their opinion, posting statement of agreements and giving examples. For example, the note thread in Figure 2 shows students brainstorming ideas for their project task on computer games. The coding of each student's note is indicated at the end of the note, in parentheses. Students' names have been coded S1, S2, S3, S4 and S5 to maintain anonymity.

These interactions focused mainly on students' asking and responding to questions that included expressions of social interchange among participants, in particular, Forum 1. They gained social knowledge about who their peers were and how to communicate with them in this environment. They brainstormed ideas and provided various examples. However, there was little evidence of construction of new knowledge, critical analysis of peers' ideas or instances of negotiation. Instead, the evidence indicated that the majority of interactions were related to the elaboration of existing beliefs and knowledge. Students expressed their own understandings of concepts and exchanged views with peers. This exchange of information consolidated participants' existing knowledge frameworks and therefore served to consolidate the learning experience. While this learning activity added little to the knowledge base itself, it nevertheless offered an insight into students' articulation of their existing knowledge.

The forum did not seem to foster testing and revision of project ideas and negotiation of meaning, which were processes fundamental to higher order thinking. Only a small percentage of contributions $(3.8 \%)$ could be categorised as higher order cognition (phases III, IV and V) and awareness of knowledge construction. Interestingly, a similar trend was also found in the earlier case study conducted in five primary schools' asynchronous online project-based classrooms (Jamaludin \& Quek, 2006) where students' notes mainly resided in phase I but not phase III and beyond. The findings seemed to suggest there is a need to further investigate (a) why students did not move beyond phase III of knowledge construction, (b) what teachers could do to help students achieve higher order thinking and (c) how students could interact not just socially but more cognitively, leading to deeper understanding of learning with one another. The overall design of the asynchronous online project-based learning environment should be examined in terms of dimensions such as pedagogy for learner centred learning, technological affordances of the chosen CMC tool and psycho-social learning environment of learner-learner interactions, behaviour and attitudes. However, the psycho-social was not the main focus of this paper and is not being reported in this study.

\section{Discussion}

There were two issues arising from students' asynchronous online participation and interaction in the eight weekly forums. The first issue concerns the decline of students' notes posted and read as the weeks progressed. For example, there was initiation (Forum 1: How are you?), propagation (Forum 2, 3, 4, 6) and termination (Forums 5, 7, 8) showing the irregular patterns of student activity in the online environment. To probe further as to why there was a decreasing frequency of students' notes, as seen from the sharp decrease at the mid point (after Forum 4), this could be due to the later forums that focus on planning, critiquing and reflection. It was observed that students largely lacked two areas in the systematic documentation of how planning was done and how peer critique was carried out. Perhaps the teacher-facilitator could strengthen the "just in time" instruction at this stage of project based learning. In turn, teachers 
may even need professional development courses to help them develop their expertise in scaffolding and promoting purposeful inquiry appropriate for an asynchronous project-based learning environment. As was highlighted in the primary school study (Jamaluddin \& Quek, 2006), the decrease in the number of total notes sent may be attributed to the Hawthorne effect because, as students became used to being in their online project groups, the feeling of newness and 'adventure' of this environment could have worn off (Kosiak, 2004).

The second issue concerns the limited types of students' notes and inquiry in projectbased learning. Earlier researchers' (Lipponen, Rahikainen, Lallimo, \& Hakkarainen, 2003) three types of notes (focus, feedback and function) were found to be indicative of types of notes contributed by students but limited in adequately depicting the richness of the notes. This could be due to the limited inquiry process because these students' notes were too topic-oriented and they tended to provide more information to peers (an indication of students' willingness and support for one another in project learning) rather than asking questions to prompt each other into deeper thinking. Also, the higher proportion of students' notes imply that these students were active in collaborating and developing shared project ideas in the asynchronous learning environment (refer to Table 2). Another cause of concern is the students' voices (24.4\%) that remained neutral (by not expressing their positive or negative feedback to peers). Their remaining neutral could either mean that they were not sure of their thinking position or they were just afraid to make a stand on what they think.

Another cause of concern is the irrelevant notes (about 33\%) found in the asynchronous project-based learning environment. This could be due to their uncertainty of the affordances of CMC for online communication, lack of understanding of who they were communicating with, and lack of support for one another. Also, they could be afraid of criticism from their peers, or they were not certain of their own ideas, or they were too dependent on their more able peers to provide the direction. To help students achieve quality discourse, teacher-facilitators should pay close attention in preparing students' collaborative learning in asynchronous project-based learning environment, developing students' online communication skills (e.g. seeking clarifications concerning other students' questions and theories) by having them practising the skills in the face to face classroom and critically reflecting on the group dynamics of each project group (e.g. team building activities and shared group journal).

A similar trend in primary and secondary school students' interaction was observed both in this study and the previous study (Jamaludin \& Quek, 2006), that is these students' participation notes resided mainly at phase I and to a lesser extent in phases II to V. The explanation for the large percentage of phase I notes could be that coconstruction of knowledge may not always be an observable phenomenon in the online learning environment (Kosiak 2004). Basically, IAM provided the type of discourse that was most frequently used in the online discussions and determined the progression of the postings throughout the different phases of the model. As there was no available interpretive framework to analyse students' interaction in project-based learning, students' lower mental notes (phase 1) and higher mental notes (phases II to $\mathrm{V}$ ) are inferred to contribute directly to the processes of project-based learning (refer to Table 1). To overcome this limitation, perhaps the students' interaction could be further analysed by conceptualising a more interpretive framework to enable researchers to document the collective learning of the student groups and individual learning in project-based learning. 


\section{Conclusion}

This study has provided useful evidence on high school students' participation (frequency and types of notes) and interaction (level of mental notes in phases) in the asynchronous project-based learning. A consistent pattern of predominantly studentcentred asynchronous environment has emerged (based on the high proportion of students' notes compared to the teachers' notes) and was observed in both primary school and high school studies.

Pedagogically speaking, these secondary school students' declining online participation and high proportion of low mental notes have shown clearly that these students may be facing learning, teaching and implementation issues. For example, they may be facing difficulties with the learning task, lack of cooperation among the group members, lack of teacher monitoring, feedback and facilitation, and a lack of motivation to learn in asynchronous online project-based platform. Such evidence derived from this study could help provide the rationale and justification for designing a more effective approach to structure, facilitate and engage students in the forums crafted in asynchronous project-based learning.

From the social aspect, the challenges faced by both primary and secondary school students suggest that they need to learn more about their group roles, demonstrate their involvement systematically (planning, contributing, asking questions and seeking input) and reflect on their learning at the end of each forum, in order to achieve quality learning from their participation in such asynchronous project-based learning. Teacher-facilitators could help and monitor the learners to function as cooperative groups (Zumbach, Reimann \& Koch, 2006). The use of IAM has indeed provided an insight into students' limited interaction (in primary and high schools) as indicated by their notes residing mainly in phase I but to a lesser extent in phases II to V. Thus the social interaction has yet to reach deep learning stage where there will be rich coconstruction of ideas and new knowledge.

From the technological aspect, students' understanding of the affordances of the CMC tool and use of thinking skills would also need to be examined further. A familiarisation with the asynchronous online project-based learning environment and teaching of "just in time" thinking skills should be introduced at the beginning of project lessons. This study has also contributed evidence of two key areas for follow up studies to be conducted in order to address the issues of declining trend of student participation found in subsequent forums, and the low frequency of higher mental notes found in the later phases of student interaction.

\section{References}

Beaudrie, B. P. (2000). Analysis of group problem-solving tasks in a geometry course for teachers using computer-mediated conferencing. (Doctoral dissertation, Montana State University, Bozeman, 2000). Dissertation Abstracts International, 61, 537.

Black, A. (2005). The use of asynchronous discussion: Creating a text of talk. Contemporary Issues in Technology and Teacher Education, 5(1).

http: / / www.citejournal.org/vol5/iss1/languagearts/article1.cfm

Chi, M. T. H. (1997). Quantifying qualitative analyses of verbal data: A practical guide. Journal of the Learning Sciences, 6, 271-315. 
Garrison, D. R., Anderson, T. \& Archer, W. (2001). Critical thinking, cognitive presence, and computer conferencing in distance education. The American Journal of Distance Education, 15(1), 7-23.

Gilbert, P. \& Dabbagh, N. (2005). How to structure online discussions for meaningful discourse: A case study. British Journal of Educational Technology, 36(1), 5-18.

Gunawardena, C., Lowe, C. \& Anderson, T. (1997). Analysis of a global on-line debate and the development of an interaction analysis model for examining social construction of knowledge in computer conferencing. Journal of Educational Computing Research, 17(4), 395429.

Hew, K. F. \& Cheung, W. S. (2003). Models to evaluate online learning communities of asynchronous discussion forums. Australian Journal of Educational Technology, 19(2), 241-259. http: / / www.ascilite.org.au/ajet/ajet19/hew.html

Henri, F. (1992). Computer conferencing and content analysis. In A. Kaye (Ed.), Collaborative learning through computer conferencing: The Najaden papers, Berlin: Springer-Verlag, 117-136.

Hiltz, S. (1990). Evaluating the virtual classroom. In L. Harasim (Ed.), Online education. New York: Praeger, 134-184.

Jamaludin, A. \& Quek, C. L. (2006). Using asynchronous online discussions in primary school project work. Australasian Journal of Educational Technology, 22(1), 64-87. http:/ / www.ascilite.org.au/ajet/ajet22/jamaludin.html

Kayler, M. \& Weller, K. (2007). Pedagogy, self-assessment, and online discussion groups. Educational Technology \& Society, 10(1), 136-147. http: / / www.ifets.info/journals /10_1/13.pdf

Knowlton, D. S., Knowlton, H. M. \& Davis, C. (2000). The whys and hows of online discussions. Syllabus: New Directions in Educational Technology, 13(10), 54-58.

Kosiak, J. J. (2004). Using asynchronous discussions to facilitate collaborative problem solving in college algebra. (Doctoral dissertation, Montana State University, 2004). [viewed 2 July 2009] http: / / etd.lib.montana.edu/ etd/2004/ kosiak/KosiakJ0805.pdf

Lakkala, M., Lallimo, J., \& Hakkarainen, K. (2005). Teachers' pedagogical designs for technology-supported collective inquiry: A national case study. Computers $\mathcal{E}$ Education, 45(3), 337-356.

Lipponen, L. (2000). Towards knowledge building discourse: From facts to explanations in primary students' computer mediated discourse. Learning Environments Research, 3, 179-199.

Lipponen, L. \& Lallimo, J. (2004). From collaborative technology to collaborative use of technology: designing learning oriented infrastructures. Educational Media International, 41(2), 111-116.

Lipponen, L., Rahikainen, M., Lallimo, J. \& Hakkarainen, K. (2003). Patterns of participation and discourse in elementary students' computer-supported collaborative learning. Learning and Instruction, 13(5), 487-509.

Mason, R. (1991). Methodologies for evaluating applications of computer conferencing. In A. R. Kay (Ed.), Collaborative learning through computer conferencing. Berlin: Springer Verlag.

Ministry of Education (1999). Project work guidelines. Singapore: Curriculum Planning \& Development Division (CPDD) and Testing \& Assessment Branch (TAB). 
Newman, D. R., Webb, B. \& Cochrane, C. (1995). A content analysis method to measure critical thinking and computer supported group learning. Interpersonal Computing and Technology: An Electronic Journal for the 21st Century, 3(2), 56-77. [verified 5 May 2010]

http: / / www.emoderators.com/ipct-j/ 1995/n2/ newman.html

Romiszowski, A. \& Mason, R. (2004). Computer-mediated communication. In D. H. Jonassen (Ed.), Handbook of research for educational communications and technology, 2nd Ed. (pp. 397-431). New York: Macmillan.

Yeo, T. M. \& Quek, C. L. (2008). Investigating design \& technology students' participation in a technology- mediated learning environment. Australasian Journal of Educational Technology, 24(5), 540-555. http: / / www.ascilite.org.au / ajet/ajet24/yeo.html

Zumbach, J., Reimann, P. \& Koch, S. (2006). Monitoring students' collaboration in computermediated collaborative problem-solving: Applied feedback approaches. Journal of Educational Computing Research, 35(4), 399-424.

Associate Professor Quek Choon Lang, Learning Sciences \& Technologies

National Institute of Education, Nanyang Technological University

1 Nanyang Walk, Singapore 637616

Email: choonlang.quek@nie.edu.sg

Web: http: / / eduweb.nie.edu.sg/LST/facultyandstaff/QuekChoonLang.asp\# 